Clemson University

TigerPrints

7-2019

Do My Students Know I Don't Like Writing? Shifting Attitudes and Instruction

Anna H. Hall

Follow this and additional works at: https://tigerprints.clemson.edu/eugene_pubs

Part of the Educational Methods Commons 


\section{Do My Students Know I Don't Like Writing? Shifting Attitudes and Instruction}

\section{Pause and Ponder}

- Do you have positive or negative attitudes toward writing?

- How do your attitudes influence how you teach writing?

- How do you foster a community of writers in your classroom?

Many elementary school teachers are jacks-of-all-trades, required to teach all academic areas, despite your personal attitudes or knowledge level about each subject. If this describes your role as a teacher, you may rarely feel equal enthusiasm about teaching reading, writing, mathematics, science, and social studies every day and with every new unit. In fact, like most teachers, you could probably describe your one or two favorite subjects to teach and why.

Many years of school experiences, personal propensities, preparation for teaching, and past success in teaching subjects contributes to the development of attitudes toward different academic subjects. Your attitudes toward subjects can affect the strategies you use, how much time you spend on the subject, your quality of instruction, and your willingness to try new strategies (Bandura \& Schunk, 1981; Robinson \& Adkins, 2002; Street, 2003). In order to provide a well-rounded education to all students, it is important to reflect on how your attitudes affect your teaching and work to ensure students have a chance to pursue and enjoy every subject with equal vigor.

\section{The Complexities of Teaching Writing}

Writing is a subject area often neglected by teacher education programs and many teachers have negative attitudes toward writing due to years of receiving red marks on their papers in K-12 ${ }^{\text {th }}$ grades (Zimmerman, Morgan, \& Kidder-Brown, 2014). Writing is challenging because it is a social and cognitive process requiring a shared understanding with readers, knowledge of different subjects, and proficient vocabulary (MacArthur, Graham, \& Fitzgerald, 
2016). Writers must generate ideas, craft sentences, which can be understood by their audience, arrange paragraphs to express a coherent message, and revise to correct errors and improve organization.

Ernest Hemingway once stated, "There is nothing to writing. All you do is sit down at a typewriter and bleed". His quote illustrates the complex and difficult task of writing, even for those who consider themselves writers. Unlike tying your shoes or riding a bicycle, writing is a skill that is not necessarily easy once you become proficient. Writing constantly demands new skills in order to write for new genres and purposes in a constantly changing social world (Bazerman, 2016). "Learning to write requires writing in many situations across a lifetime. Each new situation requires solving fresh problems" (Bazerman, 2016, pg. 15).

In addition to problem solving skills, writing requires motivation, time, opportunities to write, and quality instruction (MacArthur, Graham, \& Fitzgerald, 2016). Research demonstrates that your personal attitudes toward writing affect the writing opportunities you provide for your students and the quality and choice of teaching strategies you employ (Bandura \& Schunk, 1981; Robinson \& Adkins, 2002; Street, 2003). When you entered your first classroom, you had years of personal writing experiences and had observed many examples of writing instruction. Over time, these experiences helped shape your attitudes towards writing and greatly influenced your orientation towards teaching writing (Norman \& Spencer, 2005; Street, 2003). Because teacher attitudes are a critical element in providing quality instruction, it is important for teachers with negative writing attitudes to ask how do I still teach writing to the best of my ability?

\section{Teacher Self-Reflection}

Teacher reflection is readily accepted as one of the most significant ways teachers examine their professional identities and change their practice (Schon, 1983). It can be helpful to 
reflect on specific content or ideas (Zeichner, 1994) and research has demonstrated some benefit for teacher journaling (Chitpin, 2006; Clarke, 2004; Tillman, 2003). To begin examining your attitudes about writing, consider starting your own writing journal. Reflect on what your teachers/parents/friends did along the way to help you develop your attitudes about writing. Consider the following questions:

1. What memories do you have of writing in school?

2. How did your teachers use writing in their classrooms?

3. How competent did they make you feel?

4. As a child, what value did you see in writing?

5. How did your family use writing and what messages did they send as to its value?

6. How did your classmates view writing?

7. How did you use writing in your relationships with peers?

Take some time to explore these questions in depth and decide if you will repeat positive experiences or try to break a negative cycle.

\section{Evaluating Your Writing Attitudes}

Consider further examining your beliefs about writing by taking the Writing Attitude Scale for Teachers (WAST; Hall, Toland, \& Guo, 2016). Using a Likert-type response scale, the WAST includes 10 items measuring enjoyment, interest, competence and value in writing (See full scale in Appendix A). Sample items include "I like to share my written work with others" and "I think about my writing when I am away from it." Previous research has established teachers with more positive attitudes about writing spend larger amounts of time on writing instruction and choose more innovative teaching methods (Bandura and Schunk, 1981; Street, 2003). 


\section{Evaluating Your Writing Environment}

Next, consider evaluating how well your classroom environment supports young writers using the Writing Resources and Interactions in Teaching Environments (WRITE; Gerde \& Bingham, 2012) tool. The WRITE includes 41 items across five sections: Writing Environment, Environmental Print, Teacher Models Writing, Teacher Scaffolds Children's Writing, and Independent Child Writing. Sample environmental items include presence of a word wall, and availability of writing materials in play centers, just to name a few. Classrooms providing more positive interactions around writing and more environmental supports were associated with significant increases in children's writing ability across the school year (Gerde, Bingham, \& Pendergast, 2015).

\section{Overcoming Hurdles to Writing Instruction}

While we believe teachers have the power to improve their practice through reflection, we acknowledge today's teachers face significant hurdles in providing high quality instruction. We encourage you to examine the hurdles to keeping writing at the forefront of your curriculum (e.g., busy schedule, field trips, other district mandates) and make adjustments to overcome these

hurdles. Collaborate with teammates to make a commitment to integrating more opportunities for writing and keep each other accountable at weekly grade level meetings. Consider planning writing units together with teachers who enjoy teaching writing.

If that's not possible, find a writing mentor in your building or community, or consider joining a teacher book club or professional learning community focused on writing. Research shows teachers appreciate the format of professional book clubs given they often meet multiple times over an extended period of time, versus traditional professional development workshops that meet once and provide little to no follow up (Gardiner, Cumming-Potvin \& Hesterman, 
2013). Some teachers like book clubs more because they require active learning versus simply listening to a facilitator. Furthermore, teachers who belong to a professional book club often appreciate the sense of community provided and typically find book clubs to be the most enjoyable form of professional development (Smith \& Galbraith, 2011). If your school or district does not have opportunities like these, check your local public library. They often offer opportunities to connect with other readers and writers through book clubs and writing groups. If all else fails, don't be afraid to start your own. Bring samples of your own writing, as well as work done by your students, to share and discuss with the group. Encourage others to do the same. Much can be learned from hearing others' feedback on your work and/or seeing how other teachers respond to the individual writing done by your students.

There are a variety of professional resources available on the topic of writing. In particular, we highly recommend the works of Lucy Calkins, Steve Graham, Ralph Fletcher, and Katie Wood Ray, among others. Read about and attend workshops or summer institutes on powerful writing strategies such as the process approach (National Writing Project: https://www.nwp.org/) and writing workshop (Teachers' College Reading and Writing Workshop; https://readingandwritingproject.org/about). The annual conference of the International Literacy Association (https://www.literacyworldwide.org/) also has multiple sessions on writing each year, as do most of the conferences held by state affiliates of the organization. You can find your state's chapter here: https://www.literacyworldwide.org/get-involved/ila-network/chapters.

\section{Making a Plan for Action}

Once you have had ample time to learn and reflect, formulate a comprehensive plan to create a community of writers in your classroom. Set up a writing center where children can regularly access writing materials and model its use. Add writing utensils and paper to play centers or 
other areas of the classroom to support children's use of writing in their play and work across the curriculum. Research shows children engage in more literacy-rich play when these materials are accessible (Neuman \& Roskos, 1990). Find authentic reasons to write with your children writing thank you notes to cafeteria workers, making lists of supplies needed for a science experiment, summarizing what was learned each week for the class newsletter. You might even consider starting a celebration journal to document birthdays, the birth of new siblings, a lost tooth and/or scoring the winning soccer goal.

One of the best ways to encourage writing in the classroom is by sharing your own. If that seems daunting, think about forming a new relationship with writing. Create a list of all of the ways you currently use writing in your daily life. Expand your thinking and try to see yourself as a writer in whatever way works best for you. Consider blogging, tweeting, or scrapbooking. Perhaps, you might design a website, or begin writing your own children's book. Again, don't be afraid to start small. Consider experimenting with 6-word memoirs, an initiative spawned by Smith magazine (https://www.sixwordmemoirs.com/) in which people all over the world have attempted to tell their life story in six words or less. Alternatively, you could start a gratitude journal for your family (or for your class) where you record 3-5 things you are thankful for in words or pictures. Discuss these attempts with your students so they see how all writers struggle from time to time. Students need exposure to authentic, real-time modeling of someone on a journey to improve their writing. They need to know it is not always easy.

Within your plan, make time to celebrate your students' writing and your own growth in teaching writing along the way. Regularly invite others (families, school staff and/or other children at your school) to see and hear your work. Host your own poetry slam, or author's tea and participate as a writer, not just as the one in charge. Fisher (2005) argues allowing students 
to share their writing in creative ways helps young writers feel more inspired, and helps them see how they fit into a larger community of writers. Consider inviting a local author or illustrator to visit as well. Invite your school to host a family literacy night focused on writing. Give each participant a new writer's notebook or journal and provide an opportunity for parents and children to write together about favorite family memories. Invite your own family to attend and participate alongside the families of your students.

\section{Conclusion}

In conclusion, while writing is not always easy and we may not always like it, we have a responsibility to teach it well and to foster an appreciation for writing in our students. We can all begin to do this through deeper reflection, and high quality professional development. We can make a commitment to try new instructional strategies. But, we must also be open to exploring new avenues for our own writing, and be willing to share our individual journeys as writers with our students. For if we truly want to develop a community of writers, we need to be active participants in that community, stretching and growing ourselves as writers, along with our students. 


\section{References}

Bandura, A. and Schunk, D. (1981) 'Cultivating competence, self-efficacy, and intrinsic interest through proximal self-motivation', Journal of Personality and Social Psychology, Vol. 41, No. 3, pp.586-598, doi:10.1037/022-3514.41.3.586.

Bazerman, C. (2016). What do sociocultural studies of writing tell us about learning to write? In C. MacArthur, S. Graham, \& J. Fitzgerald, Handbook of Writing Research. NY: Guilford.

Chitpin, S. (2006). The use of reflective journal keeping in a teacher education program: A popperian analysis. Reflective Practice, 7(1), 73-86.

Clarke, M. (2004). Reflection: Journals and reflective questions,: A strategy for professional learning. Australian Journal of Teacher Education, 29(2), 11-23.

Fisher, M. T. (2005). From the coffee house to the school house: The promise and potential of spoken word poetry in school contexts. English Education, 37(2), 115-131.

Gardiner, V., Cumming-Potvin, W., \& Hesterman, S. (2013). Professional learning in a scaffolded 'multiliteracies book club': Transforming primary teacher participation. Issues in Educational Research, 23(3), 357-374.

Neuman, S. \& Roskos, K. (1990). Play, print and purpose: Enriching play environments for literacy development. The Reading Teacher, 44(3), 214-221.

MacArthur, C., Graham, S. \& Fitzgerald, J. (2016). Introduction. In C. MacArthur, S. Graham, \& J. Fitzgerald, Handbook of Writing Research. NY: Guilford.

Schön, D. A. (1983). The reflective practitioner: How professionals think in action. New York, NY: Basic Books.

Street, C. (2003) 'Pre-service teachers' attitudes about writing and learning to teach writing: implications for teacher educators', Teacher Education Quarterly, Vol. 30, No. 3, pp.33- 
50.

Smith, S. \& Galbraith, Q. (2011). Library staff development: How teacher book clubs can be more effective (and less expensive) than traditional trainings. College and Undergraduate Libraries, 18, 170-182

Tillman, L. C. (2003). Mentoring, reflection and reciprocal journaling. Theory Into Practice, 42(3), 226-233.

Zeichner, K. M. (1994). Research on teacher thinking and different views of reflective practice in teaching and teacher education. In I. Carlgren, G. Handal, \& S. Vaage (Eds.), Teachers' minds and actions: Research on teachers' thinking and practice (pp. 9-27). London, UK: Falmer Press.

Zimmerman, B. S., Morgan, D. N., \& Kidder-Brown, M. K. (2014). The use of conceptual and pedagogical tools as mediators of preservice teachers' perceptions of self as writers and future teachers of writing. Action in Teacher Education, 36(2), 141-156. oi:

$0.1080 / 01626620.2014 .898598$ 


\section{Appendix A}

\section{Writing Attitude Scale for Teachers}

Thinking about your attitudes towards writing, indicate the extent to which you agree with the following statements. Respondents should choose from the following response options: Strongly Agree, Agree, Disagree, Strongly Disagree; options can be provided in a Likert matrix consisting of radio buttons to the right of each item with column headings consisting of agreement ratings.)

$1 \quad$ I write for personal enjoyment.

$2 \quad$ I like to share my written work with others.

3 I am interested in understanding different writing techniques.

$4 \quad$ I am interested in using writing in my profession.

5 I think about my writing when I am away from it.

6 My writing skills make me more employable.

7 Writing is important for me to express my feelings.

8 Writing is relevant in my life.

9 I find writing easy to accomplish.

10 It is easy to organize my ideas when I am writing. 